\title{
Correction to: Tactile Comfort Prediction of Functional Fabrics from Instrumental Data Using Intelligence Systems
}

\author{
Melkie Getnet Tadesse ${ }^{1,2,3 *}$, Yan Chen ${ }^{3}$, Lichuan Wang ${ }^{3}$, Vincent Nierstrasz ${ }^{2}$, and Carmen Loghin ${ }^{1}$ \\ ${ }^{1}$ Faculty of Textiles, Leather \& Industrial Management, Gheorghe Asachi Technical University of Iasi 53, \\ D. Mangeron Blv., Iasi-700050, Romania \\ ${ }^{2}$ Textile Materials Technology, Department of Textile Technology, Faculty of Textiles, Engineering and Business, \\ University of Borås, SE-501 90 Borås, Sweden \\ ${ }^{3}$ The College of Textile and Clothing Engineering, Soochow University, Suzhou 215006, China
}

This article is published with open access at Springerlink.com

\author{
CThe Author(s) 2019 \\ Erratum to \\ Fibers and Polymers 2019, Vol.20, No.1, 199-209 \\ https://doi.org/10.1007/s12221-019-8301-9
}

The article Tactile Comfort Prediction of Functional Fabrics from Instrumental Data Using Intelligence Systems, written by Melkie Getnet Tadesse, Yan Chen, Lichuan Wang, Vincent Nierstrasz, and Carmen Loghin, was erroneously originally published electronically on the publisher's internet portal (currently SpringerLink) on 15 February 2019 without open access. After publication this was corrected and the copyright of the article changed in April 2019 to (C) The Author(s) 2019 and the article is forthwith distributed under the terms of the Creative Commons Attribution 4.0 International License (http:// creativecommons.org/licenses/by/4.0/), which permits use, duplication, adaptation, distribution and reproduction in any medium or format, as long as you give appropriate credit to the original author(s) and the source, provide a link to the Creative Commons license and indicate if changes were made.

The original article has been corrected.

Open Access: This article is distributed under the terms of the Creative Commons Attribution 4.0 International License (http://creativecommons.org/licenses/by/4.0/), which permits use, duplication, adaptation, distribution and reproduction in any medium or format, as long as you give appropriate credit to the original author(s) and the source, provide a link to the Creative Commons license and indicate if changes were made.

\footnotetext{
*Corresponding author: melkie.tadesse@hb.se
} 